\title{
Desensitization of the Neurokinin 1 Receptor Is Mediated by the Receptor Carboxy-Terminal Region, but Is Not Caused by Receptor Internalization
}

\author{
Matthew A. Sanders and Harry LeVine III \\ Department of Biology, University of Michigan, and Department of Neuroscience Pharmacology, Parke-Davis \\ Pharmaceutical Research Division of Warner-Lambert Company, Ann Arbor, Michigan, U.S.A.
}

\begin{abstract}
The carboxy-terminal cytoplasmic regions of the rat neurokinin 1 (substance $P$ ) and neurokinin 2 (neurokinin $A$ ) receptors have been exchanged to determine if this region of the neurokinin 1 receptor is involved in its desensitization. When expressed at similar levels in stably transfected Chinese hamster ovary $(\mathrm{CHO})$ cell lines, receptors containing the carboxy-terminal region of the neurokinin 1 receptor desensitized significantly more (as measured by reduction of the inositol 1,4,5-trisphosphate response) when preexposed for $1 \mathrm{~min}$ to $1 \mu \mathrm{M}$ neurokinin, indicating a role for the carboxy-terminal region of the neurokinin 1 receptor in its desensitization. Measurement of receptor internalization using radiolabeled neurokinins $(0.3 \mathrm{nM})$ indicated that $\sim 75-80 \%$ of the receptors were internalized in each cell line after 10 min at $37^{\circ} \mathrm{C}$, with no observable correlation between neurokinin receptor desensitization and internalization. Measurement of loss of receptor surface sites for cell lines CHO NK1 and CHO NK1NK2 following exposure to 1 $\mu M$ substance $P$ also indicated no obvious relationship between the percent desensitization and percent of receptors internalized. Also, two inhibitors of neurokinin 1 receptor internalization, phenylarsine oxide and hyperosmolar sucrose, did not inhibit neurokinin 1 receptor desensitization. The protein kinase inhibitors Ro 31-8220, staurosporine, and $\mathrm{Zn}^{2+}$ had no effect on neurokinin 1 receptor desensitization, indicating that the kinases affected by these agents are not rate-limiting in neurokinin 1 receptor desensitization in this system. Key Words: Receptor desensitization - Receptor internalization Phosphoinositide hydrolysis - Chimeric receptors.

J. Neurochem. 67, 2362-2372 (1996).
\end{abstract}

The mammalian neurokinin system consists of three neuropeptides ( substance $P$, neurokinin $A$, and neurokinin $B$ ) and three corresponding receptors, neurokinin 1-3 (NK 1-3), which are members of the septahelical transmembrane domain $\mathrm{G}$ protein-coupled receptor superfamily (Masu et al., 1987; Yokota et al., 1989; Hershey and Krause, 1990; Shigemoto et al., 1990). Although considerable progress has been made in the determination of neurokinin receptor domains involved in ligand and antagonist binding (reviewed by McLean and Lowe, 1994) and in coupling to signal transduction pathways (Blount and Krause, 1993; reviewed by Krause et al., 1994), regions of the receptors involved in desensitization (defined as loss of responsiveness to repeated or prolonged agonist stimulation) have not been clearly determined. Rat neurokinin receptors expressed in Xenopus oocytes display dramatic differences in desensitization (a 1-2-min exposure followed by a 10-min wash) of the three receptors, with the NK1 receptor desensitizing strongly, the NK3 receptor somewhat, and the NK2 receptor only slightly, as measured by $\mathrm{Ca}^{2+}$-induced $\mathrm{Cl}^{-}$flux (Nakanishi et al., 1990). In rat parotid acinar cells the NK1 receptor undergoes homologous (desensitization is specific to agonist-occupied receptor) but not heterologous (receptors not occupied by agonist become desensitized) desensitization, because stimulation of inositol phosphate formation by the muscarinic acetylcholine receptor agonist carbachol has no effect on the subsequent response to substance P (Sugiya et al., 1987). In both the Xenopus expression system and rat parotid acinar cells, desensitization of the NK1 receptor occurs within minutes of exposure to substance $\mathrm{P}$. In rat parotid acinar cells desensitization is associated with a rapid loss of receptor surface sites, indicating receptor internalization as a potential mechanism of desensitization, although no cause-effect relationship has been demonstrated (Sugiya et al., 1988). Because the third intra-

Received June 11, 1996; revised manuscript received July 31 , 1996; accepted August 1, 1996

Address correspondence and reprint requests to Dr. H. LeVine III at Department of Neuroscience Pharmacology, Parke-Davis Pharmaceutical Research, 2800 Plymouth Road, Ann Arbor, MI 48105, U.S.A.

Abbreviations used: CHO cells, Chinese hamster ovary cells; DMEM/F12, 1:1 (vol/vol) Dulbecco's modified Eagle's medium/ Ham's nutrient mixture F12; GRK, G protein receptor kinase: $\mathrm{I}(1,4,5) \mathrm{P}_{3}$, inositol $1,4,5$-trisphosphate; NK1, neurokinin 1 (substance $P$ ) receptor; NK2, neurokinin 2 (neurokinin $A$ ) receptor; $\mathrm{NK} 3$, neurokinin 3 (neurokinin $\mathrm{B}$ ) receptor; PIC, phosphoinositidespecific phospholipase $\mathrm{C}$; PKC, protein kinase $\mathrm{C}$. 
cellular loop and C-terminal cytoplasmic region of the rat NK1 receptor contain a large number of serines and threonines (five in the third loop, 26 in the Cterminal region), phosphorylation of the NK1 receptor by serine-threonine kinases has been proposed to be potentially involved in its desensitization (Ohkubo and Nakanishi, 1991).

In this study we compare desensitization properties of the rat NK1, NK2, and chimeric NK1-NK2 receptors in which the $\mathrm{C}$-terminal cytoplasmic region of the receptors is exchanged. Desensitization was characterized by measurement of the inositol 1,4,5-trisphosphate $\left[\mathrm{I}(1,4,5) \mathrm{P}_{3}\right]$ response in transfected Chinese hamster ovary $(\mathrm{CHO})$ cells expressing similar levels of each receptor. The role of receptor internalization in $\mathrm{NK} 1$ receptor desensitization was examined through comparison of internalization properties of the neurokinin receptors and treatment of CHO NK1 cells with inhibitors of receptor internalization. Finally, the role of protein kinases in NK1 receptor desensitization was examined by determining the effect of various protein kinase inhibitors on NK1 receptor desensitization.

\section{MATERIALS AND METHODS}

\section{Materials}

pRc/CMV expression vector was purchased from Invitrogen. ${ }^{125} \mathrm{I}-\mathrm{Substance} \mathrm{P}(2,000 \mathrm{Ci} / \mathrm{mmol})$, myo- $\left[{ }^{3} \mathrm{H}\right]$ inositol $\left(80 \mathrm{Ci} / \mathrm{mmol}\right.$; with PT6-271), and $\left[{ }^{3} \mathrm{H}\right]$ substance $\mathrm{P}(26-56 \mathrm{Ci} / \mathrm{mmol})$ were supplied by Amersham. ${ }^{125} \mathrm{I}-\mathrm{Neu}$ rokinin $\mathrm{A}(2,200 \mathrm{Ci} / \mathrm{mmol})$ and $\left[{ }^{3} \mathrm{H}\right] \mathrm{I}(1,4,5) \mathbf{P}_{3}(20 \mathrm{Ci} /$ mmol) were from New England Nuclear. $\left[{ }^{3} \mathrm{H}\right]$ Neurokinin A ( $114 \mathrm{Ci} / \mathrm{mmol})$ was purchased from Xeneca. Filters used for $\mathrm{I}(1,4,5) \mathrm{P}_{3}$ assay (FP105/GFB for the model M48R Brandel cell harvester) were obtained from Brandel. Neurokinin $A$ and substance $P$ were purchased from Bachem. Staurosporine and the restriction enzymes $C v n \mathrm{I}$ and DraII were purchased from Boehringer Mannheim. The restriction enzymes $A c c \mathrm{I}$ and PstI and other enzymes used in making receptor constructs were from GibcoBRL. Cell culture reagents were from GibcoBRL. Ro 31-8220 was purchased from Calbiochem. Frozen bovine cerebellum was obtained from Pel-Freez. Other reagents were from Sigma unless indicated

\section{Neurokinin receptor constructs}

cDNA clones of rat neurokinin receptors in Bluescript $\mathrm{SK}^{+}$were generously supplied by $\mathrm{S}$. Nakanishi. Chimeric neurokinin receptors (NK1NK2, N-terminal region of NK1, C-terminal region of NK2; NK2NK1, N-terminal region of NK2, C-terminal region of NK1) were constructed by exchanging the $\mathrm{C}$-terminal region at the unique $A c c \mathrm{I}$ site, which is present at the same position in the seventh transmembrane domain of each receptor. For expression in $\mathrm{CHO} \mathrm{K} 1$ cells, constructs were transferred from Bluescript $\mathrm{SK}^{+}$to the eukaryotic expression vector $\mathrm{pRc/CMV} \mathrm{(Invitrogen).} \mathrm{In} \mathrm{mak-}$ ing neurokinin receptor constructs, restriction sites were used to transfer a minimum of noncoding region so that the first methionine was that at the beginning of the receptor open reading frame: NK1, C vnI site at -110 ; NK1NK2, DraII site at -91 ; NK2, PstI site at -36 ; and NK2NK1, PstI site at -36 .

\section{Stable expression in CHO K1 cells}

Twenty micrograms of $\mathrm{pRc} / \mathrm{CMV}$ DNA containing the cloned neurokinin receptor constructs was used to transfect CHO K1 cells $\left(3 \times 10^{6}\right.$ cells in a $1-\mathrm{ml}$ BRL electroporation chamber) by electroporation ( $800 \mu \mathrm{F}, 300 \mathrm{~V}$, low Ohms on a BRL Cell-Porater). The transfected CHO K1 cells were then plated out at various dilutions $\left(1,4\right.$, and $\left.16 \times 10^{3}\right)$ per 100 -mm-diameter plate in 1:1 (vol/vol) Dulbecco's modified Eagle's medium/Ham's nutrient mixture F12 (DMEM/ F12), $10 \%$ calf serum, $20 \mu \mathrm{g} / \mathrm{ml}$ streptomycin, 20 units/ $\mathrm{ml}$ penicillin, and $500 \mu \mathrm{g} / \mathrm{ml} \mathrm{G} 418$ for selection of stably transfected cell lines. Cells were maintained in a 95\% air/ $5 \% \mathrm{CO}_{2}$ atmosphere. After 10 days, clonal cell lines were selected and propagated. After several more passages in selective media, clonal cell lines were screened for binding of the appropriate neurokinin. Cell lines used for characterization of desensitization were maintained for at least 10 passages before use in experiments and tested for expression level several times to isolate cell lines of comparable expression levels. Cell lines were continuously maintained in DMEM/F12 containing $10 \%$ calf serum, $20 \mu \mathrm{g} / \mathrm{ml}$ streptomycin, 20 units $/ \mathrm{ml}$ penicillin, and $500 \mu \mathrm{g} / \mathrm{ml} \mathrm{G418.}$

\section{Binding assays}

Subconfluent cells ( $\sim 80 \%$ confluent $)$ were harvested and resuspended in Dulbecco's phosphate-buffered saline (GibcoBRL) with (for $\left[{ }^{3} \mathrm{H}\right]$ neurokinin $A$ ) or without (for $\left[{ }^{3} \mathrm{H}\right]-$ substance $\mathrm{P}$ ) $\mathrm{Ca}^{2+}$ and $\mathrm{Mg}^{2+}$, containing $0.2 \mathrm{mg} / \mathrm{ml}$ bovine serum albumin, $5 \mu \mathrm{g} / \mathrm{ml}$ chymostatin, $5 \mu \mathrm{g} / \mathrm{ml}$ leupeptin, and $0.04 \mathrm{mg} / \mathrm{ml}$ bacitracin, because $\left[{ }^{3} \mathrm{H}\right]$ neurokinin $\mathrm{A}$ binding is enhanced in the presence of $\mathrm{Ca}^{2+} / \mathrm{Mg}^{2+}$ (Aharoney et al., 1995). Binding assays contained 400,000-1,000,000 cells in a volume of $100-250 \mu \mathrm{l}$. For $\mathrm{CHO} \mathrm{NK} 1$ and $\mathrm{CHO}$ NK1NK2, binding assays used $0.3-20 \mathrm{n} M\left[{ }^{3} \mathrm{H}\right]$ substance $\mathrm{P}$; for CHO NK2, 1.0-30nM $\left[{ }^{3} \mathrm{H}\right]$ neurokinin $\mathrm{A}$; and for CHO NK2NK1, 1.0-70 $\mathrm{n}\left[{ }^{3} \mathrm{H}\right]$ neurokinin A. Nonspecific binding was measured using unlabeled neurokinin at 1,000 times the highest concentration of $\left[{ }^{3} \mathrm{H}\right]$ neurokinin used. Binding assays were incubated for $90 \mathrm{~min}$ on ice and then centrifuged $15 \mathrm{~s}$ at $16,000 \mathrm{~g}(14,000 \mathrm{rpm})$ in an Eppendorf microfuge. Cell pellets were solubilized in $2 \%$ (wt/vol) sodium dodecyl sulfate, added to $10 \mathrm{ml}$ of Beckman ReadyGel, and counted for radioactivity in a Beckman model LS $6000 \mathrm{IC}$ scintillation counter. Counts were corrected for quenching and expressed as dpm values. Binding data were analyzed using EBDA/Ligand.

\section{$I(1,4,5) P_{3}$ assays}

The procedure used was similar to that of Bredt et al. (1989). Cells at $\sim 80 \%$ confluency were harvested, resuspended in media without serum $(\sim 1,000,000$ cells $/ 50 \mu \mathrm{l})$, and incubated at $37^{\circ} \mathrm{C}$ for $30 \mathrm{~min}$. Cells were then stimulated with $1 \mu M$ substance $\mathrm{P}$ (NK1 and NK1NK2) or $10 \mu M$ neurokinin $A$ (NK2 and NK2NK1) in DMEM/F12 or $\mathrm{DMEM} / \mathrm{F} 12$ vehicle (final volume, $200 \mu \mathrm{l}$ ) for the appropriate interval at $37^{\circ} \mathrm{C}$ and quenched by addition of an equal volume of ice-cold $15 \%$ (wt/vol) trichloroacetic acid. Samples were then extracted twice on ice with $10 \times$ volumes of water-saturated diethyl ether to remove trichloroacetic acid; then the aqueous phase was heated to $50^{\circ} \mathrm{C}$ for $5-10 \mathrm{~min}$ to evaporate residual ether from the samples. One-tenth volume of $5 \% \mathrm{NaHCO}_{3}$ was then added to bring samples to a neutral $\mathrm{pH}$, and samples were stored at $-80^{\circ} \mathrm{C}$ until determination of $\mathbf{I}(1,4,5) \mathrm{P}_{3}$ content. For $\mathbf{I}(1,4,5) \mathrm{P}_{3}$ assays, bovine cerebellar membranes prepared according to the procedure of Bredt et 

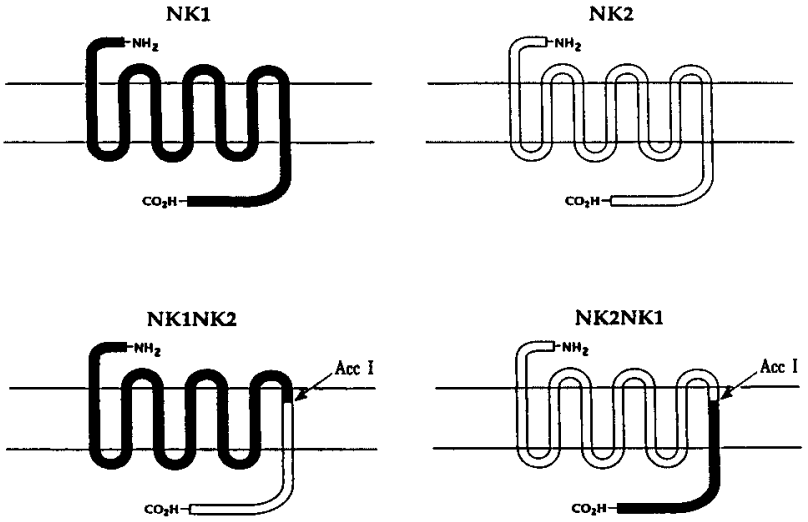

FIG. 1. Diagram of neurokinin receptor constructs shows the site of exchange at the $\mathrm{Accl}$ site in the seventh transmembrane domain to form chimeric neurokinin receptors. $\mathrm{NH}_{2}$, amino terminus of receptor; $\mathrm{CO}_{2} \mathrm{H}$, carboxy terminus of receptor.

al. (1989) were used as the source of $\mathrm{I}(1,4,5) \mathrm{P}_{3}$ receptor. I $(1,4,5) \mathrm{P}_{3}$ assays contained $20,000 \mathrm{dpm}(1 \mathrm{n} M)$ of $\left[{ }^{3} \mathrm{H}\right]-$ $\mathrm{I}(1,4,5) \mathrm{P}_{3}, 50 \mathrm{~m} M$ Tris-HCl (pH 8.4), $1 \mathrm{~m} M$ EDTA, 1 $\mathrm{m} M$ dithiothreitol, and enough membranes to give $\sim 5,000$ $\mathrm{dpm}$ of binding in a total volume of $500 \mu \mathrm{l}$. After $1 \mathrm{~h}$ on ice, assays were either centrifuged $(11,000 \mathrm{~g}, 5 \mathrm{~min})$ or harvested using a Brandel cell harvester (model M48R; FP105/GFB filters) and rinsed three times with $3 \mathrm{ml}$ of icecold $50 \mathrm{~m} M$ Tris- $\mathrm{HCl}, 1 \mathrm{~m} M$ EDTA, and $1 \mathrm{~m} M$ dithiothreitol, $\mathrm{pH}$ 8.4. After the reaction mixture was aspirated, membranes obtained by centrifugation were solubilized in $2 \%$ (wt/vol) sodium dodecyl sulfate and then added to $10 \mathrm{ml}$ of Beckman Ready-Gel. For assays harvested by the Brandel cell harvester, $7.5 \mathrm{ml}$ of Beckman Ready Protein was added to the filters, and filters were allowed to sit for at least $12 \mathrm{~h}$ before counting to completely recover radioactivity. Similar results were obtained by either method. Levels of $\mathrm{I}(1,4,5) \mathrm{P}_{3}$ [expressed as picomoles of $\mathrm{I}(1,4,5) \mathrm{P}_{3}$ per $10^{6}$ cells] were determined by comparison with a standard curve calibrated using DMEM/F12 containing 15\% (wt/vol) trichloroacetic acid processed in the same manner as the sample unknowns. Radioactivity was determined in a Beckman model LS $6000 I C$ scintillation counter. Counts were corrected for quenching and expressed as dpm values.

\section{Desensitization and response recovery}

Cells at $\sim 80 \%$ confluency were harvested, resuspended in DMEM/F12 without serum, and incubated at $37^{\circ} \mathrm{C}$ for 30 min. Cells (final concentration, $\sim 4 \times 10^{8} / \mathrm{ml}$ ) were exposed to $1 \mu M$ substance $\mathrm{P}$ (NK1 and NK2NK1) or $1 \mu M$ neurokinin $A(N K 2$ and NK2NK1) in DMEM/F12 or DMEM/F12 vehicle (control) for $1 \mathrm{~min}$ at $37^{\circ} \mathrm{C}$. Desensitization was stopped by adding $5 \times$ volumes of ice-cold DMEM/F12 and immediately centrifuging cells at low speed (several short pulses in an Eppendorf microfuge). Cells were rinsed three more times with ice-cold DMEM/F12, with the final rinse lasting $2 \mathrm{~h}$ at $4^{\circ} \mathrm{C}$. Cells were then resuspended at $\sim 1,000,000$ cells $/ 50 \mu \mathrm{l}$ on ice, allowed to recover for $5 \mathrm{~min}$ (desensitization experiments) or various intervals (response recovery experiments) at $37^{\circ} \mathrm{C}$, and then stimulated with the appropriate neurokinin at $10 \mu M$ in DMEM/F12 or DMEM/ F12 vehicle in a final volume of $200 \mu \mathrm{l}$. Assays were quenched with an equal volume of ice-cold $15 \%(\mathrm{wt} / \mathrm{vol})$ trichloroacetic acid at $10 \mathrm{~s}$, the point at which the maximal $\mathrm{I}(1,4,5) \mathrm{P}_{3}$ response occurred. Levels of $\mathrm{I}(1,4,5) \mathrm{P}_{3}$ were then determined as described above for the $\mathrm{I}(1,4,5) \mathrm{P}_{3}$ assay. Desensitization was expressed as the reduction in $\mathbf{I}(1,4,5) \mathbf{P}_{3}$ response in preexposed cells compared with the control: $\{1$ $-\left[\right.$ desensitized $\mathrm{I}(1,4,5) \mathrm{P}_{3}$ response/control $\mathrm{I}(1,4,5) \mathrm{P}_{3}$ response ] $\times 100$

\section{Receptor internalization}

Cells at $\sim 80 \%$ confluency were harvested and resuspended in DMEM/F12 without serum $(\sim 8,000,000$ cells/ $\mathrm{ml}$ ) containing $0.2 \mathrm{mg} / \mathrm{ml}$ bovine serum albumin, $5 \mu \mathrm{g} / \mathrm{ml}$ chymostatin, $5 \mu \mathrm{g} / \mathrm{ml}$ leupeptin, $0.04 \mathrm{mg} / \mathrm{ml}$ bacitracin, and the appropriate radiolabeled neurokinin (for NKI and NK1NK2, ${ }^{125}$ I-substance P; for NK2 and NK2NK1, ${ }^{125}$ I-neurokinin A) at $0.3 \mathrm{n} M$. Nonspecific binding was measured in the presence of $1 \mu M$ unlabeled neurokinin. Cells were allowed to bind neurokinin to equilibrium at $4^{\circ} \mathrm{C}$ (to prevent internalization ) for $90 \mathrm{~min}$, and then $30-50-\mu \mathrm{l}$ aliquots of the cell suspension $\left(3-5 \times 10^{5}\right.$ cells $)$ were shifted to $37^{\circ} \mathrm{C}$ for various intervals. Internalization was quenched by addition of $10 \times$ volumes of ice-cold binding buffer, and cells were immediately placed on ice. After low-speed centrifugation (several short bursts in an Eppendorf microfuge), cells were rinsed once with ice-cold binding buffer and then with $20 \mathrm{~m} M$ sodium acetate ( $\mathrm{pH} 3.5$ ) and $150 \mathrm{~m} \mathrm{M} \mathrm{NaCl}$ for 30 min in the cold to remove surface-bound neurokinin. An aliquot of the wash was saved for counting. The remainder of the wash was vacuum-aspirated, and the cell pellet was counted directly in the tube. Samples were counted in a Packard Cobra autogamma counter. Internalization was expressed as the percentage of total cpm bound (pellet + acid wash) associated with the pellet fraction at a given time: [cpm in pellet/ $(\mathrm{cpm}$ in pellet $+\mathrm{cpm}$ in wash $)] \times 100$.

For measurement of receptor surface site loss, $\sim 80 \%$ confluent cells were harvested and resuspended in DMEM/F12. Cells were then allowed to sit at $37^{\circ} \mathrm{C}$ for $30 \mathrm{~min}$ and then stimulated with $1 \mu M$ substance $\mathrm{P}$ for various intervals (final concentration of cells, $\sim 10,000,000 / \mathrm{ml}$ ). Internalization was stopped by addition of $5 \times$ volumes of ice-cold DMEM/ F12, and cells were immediately placed on ice. Cells were then rinsed as described for measurement of desensitization. Receptor surface sites were then quantified as described for binding assays, using $20 \mathrm{n} M\left[{ }^{3} \mathrm{H}\right]$ substance $\mathrm{P}$ and $30 \mathrm{n} M$ $\left[{ }^{3} \mathrm{H}\right]$ substance $\mathrm{P}$ to quantify receptor surface sites for the CHO NK1 and CHO NK1NK2 cell lines, respectively. These

TABLE 1. Summary of Scatchard analysis for $\mathrm{CHO}$ neurokinin cell lines

\begin{tabular}{lccr}
\hline \multicolumn{1}{c}{ Cell line } & $K_{\mathrm{D}}(\mathrm{n} M)$ & $\begin{array}{c}B_{\max } \\
\text { (receptors/cell) }\end{array}$ & $\mathrm{n}$ \\
\hline CHO NK1 & $0.85 \pm 0.27$ & $104,000 \pm 40,200$ & 4 \\
CHO NK2 & $9.0 \pm 0.58$ & $155,000 \pm 52.700$ & 4 \\
CHO NK1NK2 & $1.41 \pm 0.09$ & $27,500 \pm 7,000$ & 4 \\
& $15.1 \pm 2.1$ & $93,000 \pm 20,500$ & \\
CHO NK2NK1 & $46.5 \pm 9.2$ & $148,000 \pm 39,300$ & 3 \\
\hline
\end{tabular}

$K_{\mathrm{D}}$ and $B_{\max }$ data are mean $\pm \mathrm{SEM}$ values determined from three or four separate experiments $(n)$ performed in triplicate. Experiments were performed as described in Materials and Methods using either $\left[{ }^{3} \mathrm{H}\right]$ substance $\mathrm{P}$ (NK1 and NK1NK2) or $\left[{ }^{3} \mathrm{H}\right]$ neurokinin A (NK2 and NK2NK1). 
FIG. 2. Time courses of $(1,4,5) P_{3}$ formation for the $\mathrm{CHO}$ cell lines (O) CHO NK1 (A) and CHO NK1NK2 (B) stimulated with $1 \mu M$ substance $\mathrm{P}$ or $\mathrm{CHO}$ NK2 (C) and CHO NK2NK1 (D) stimulated with $1 \mu \mathrm{M}$ neurokinin $A$ in DMEM/F12 for the indicated intervals at $37^{\circ} \mathrm{C}$. Cells stimulated with DMEM/F12 vehicle for the indicated intervals at $37^{\circ} \mathrm{C}$ are also shown ( $\square$ ). Assays were quenched at the times indicated with an equal volume of ice-cold $15 \%(\mathrm{vol} / \mathrm{vol})$ trichloroacetic acid, and levels of $I(1,4,5) \mathrm{P}_{3}$ were determined as described in Materials and Methods. Data are mean \pm SD (bars) values from one of two or more representative experiments performed in triplicate with similar results.

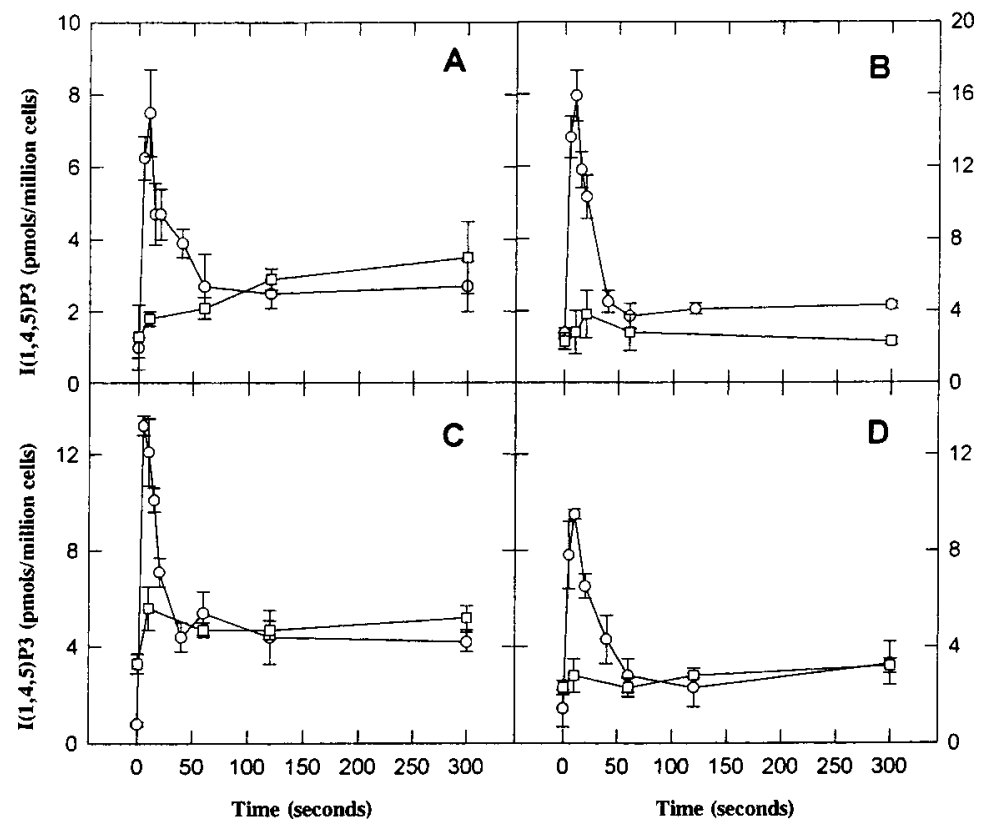

binding assays were performed on ice to prevent further receptor internalization.

\section{Statistical treatments}

Where appropriate, data were analyzied using the unmatched or matched-pair two-tailed $t$ test. Differences were considered significant when $p<0.05$.

\section{RESULTS}

\section{Neurokinin receptor constructs and stably transfected $\mathrm{CHO}$ cell lines}

Chimeric neurokinin receptors were prepared in which the NK1 and NK2 receptor C-terminal cytoplasmic regions were exchanged at the unique $A c c \mathrm{I}$ site present in the same position in the seventh transmembrane domain of both receptors. Strong sequence identity between the two receptors in this transmembrane domain ( 18 of 20 amino acids identical), which is thought to serve as part of the recognition site for the common C-terminal neurokinin sequence (Yokota et al., 1992), allowed the exchange of the C-terminal region with little effect on other regions of the receptor. Diagrams of the neurokinin receptor constructs are shown in Fig. 1. For expression in eukaryotic cells, the constructs were placed into the eukaryotic expression vector $\mathrm{pRc} / \mathrm{CMV}$ under control of the cytomegalovirus promoter. Stable $\mathrm{CHO}$ neurokinin receptor cell lines were established to allow comparison of cell lines expressing similar levels of neurokinin receptors. Expression levels of neurokinin receptor in the cell lines were monitored over a 1-2-month period. To obtain a sufficient functional response for the analysis of desensitization, cell lines were chosen that expressed between 104,000 and 155,000 receptors per cell as determined by Scatchard analysis (Table 1 ).
I (1,4,5) $P_{3}$ response of $\mathrm{CHO}$ neurokinin cell lines

Time courses of $\mathrm{I}(1,4,5) \mathrm{P}_{3}$ formation for the $\mathrm{NK} 1$, NK2, and C-terminal chimeric NK1NK2 and NK2NK1 cell lines are shown in Fig. 2. Although the amplitude of the peak response differed somewhat between cell lines, the response was qualitatively similar for all cell lines. Levels of $\mathrm{I}(1,4,5) \mathrm{P}_{3}$ peaked at $\sim 10 \mathrm{~s}$ and then returned to near basal levels within $1 \mathrm{~min}$. When time courses were carried out to $30 \mathrm{~min}$ for the CHO NKI

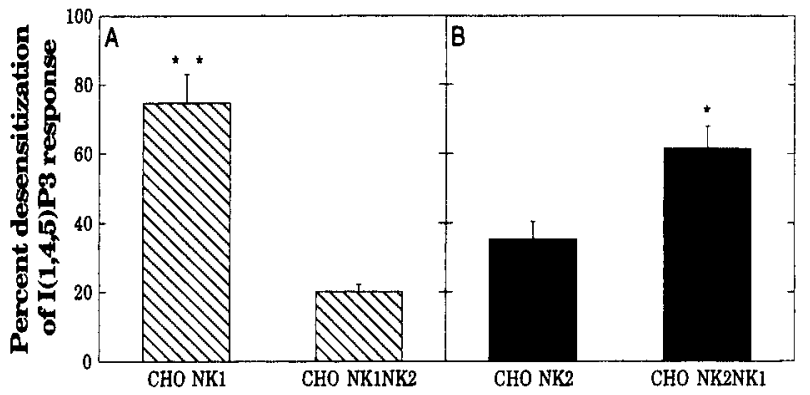

FIG. 3. Desensitization of $1(1,4,5) \mathrm{P}_{3}$ response for $\mathrm{CHO}$ neurokinin cell lines. Cells were stimulated with $(\mathbf{A}) 1 \mu M$ substance $P$ (CHO NK1 and CHO NK1NK2) or (B) $1 \mu M$ neurokinin A (CHO NK2 and CHO NK2NK1) in DMEM/F12 or DMEM/F12 vehicle (controls for each cell line) for $1 \mathrm{~min}$, rinsed in the cold as described in Materials and Methods, and then allowed to recover for $5 \mathrm{~min}$ at $37^{\circ} \mathrm{C}$. Cells were then stimulated with the appropriate neurokinin for $10 \mathrm{~s}$ at $10 \mu \mathrm{M} . \mathrm{I}(1,4,5) \mathrm{P}_{3}$ levels were then determined as described in Materials and Methods. Data are mean + SEM (bars) values from three independent experiments done in quintuplicate. Assays were performed in parallel for the cell lines being compared in $A$ and $B$. In $A, C H O N K 1$ desensitizes significantly more than $\mathrm{CHO}$ NK1NK2: ${ }^{* \star} p<0.01$ by two-tailed $t$ test. In $\mathrm{B}, \mathrm{CHO}$ NK2NK1 desensitizes significantly more than CHO NK2: ${ }^{*} p<0.05$ by two-tailed $t$ test. 


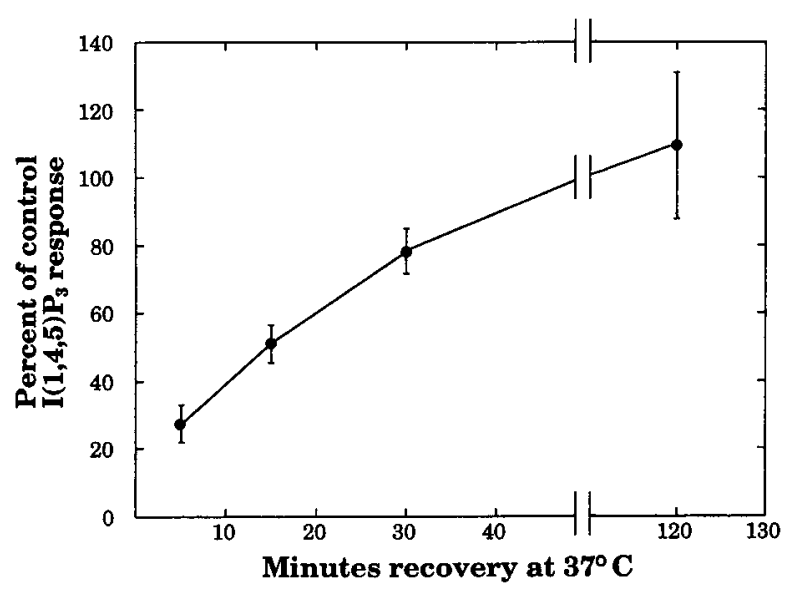

FIG. 4. Time course of $I(1,4,5) P_{3}$ response recovery for cell line $\mathrm{CHO}$ NK1. CHO NK1 cells were stimulated with $1 \mu M$ substance $P$ in DMEM/F12 or DMEM/F12 vehicle (controls for each cell line) for $1 \mathrm{~min}$, rinsed in the cold as described in Materials and Methods, and then allowed to recover after rinsing for the times indicated at $37^{\circ} \mathrm{C}$. Cells were then stimulated with $10 \mu \mathrm{M}$ substance $P$ for $10 \mathrm{~s}$, and $1(1,4,5) \mathrm{P}_{3}$ levels were determined as described in Materials and Methods. Data are mean \pm SEM (bars) values from five independent experiments done in triplicate or quadruplicate $(5-, 15-$, and 30 -min time points) or mean \pm range (bars) values from two independent experiments done in quintuplicate (120-min time point). Note that results are expressed as percentages of control response $\left\{\left[1(1,4,5) \mathrm{P}_{3}\right.\right.$ response of treated cells $/(1,4,5) \mathrm{P}_{3}$ response of control] $\left.\times 100\right\}$ rather than, as in Figs. 3,6 , and 7 , percent desensitization: $\{1$ - $\left[I(1,4,5) P_{3}\right.$ response of treated cells $/ I(1,4,5) P_{3}$ response of control] $\} \times 100$.

and CHO NK1NK2 cell lines, no further changes in levels of $\mathrm{I}(1,4,5) \mathrm{P}_{3}$ relative to baseline were observed (data not shown). For all four cell lines expressing the wild-type receptors and the two chimeric constructs, although levels of $\mathrm{I}(1,4,5) \mathrm{P}_{3}$ returned to near baseline within 1 min, accumulation of total ${ }^{3} \mathrm{H}$-inositol phosphates continued out to $30 \mathrm{~min}$ in $\mathrm{Li}^{+}$-treated cells prelabeled with $\left[{ }^{3} \mathrm{H}\right]$ inositol (data not shown), indicating that $\mathrm{I}(1,4,5) \mathrm{P}_{3}$ was still being produced after $1 \mathrm{~min}$.

\section{Desensitization of $I(1,4,5) P_{3}$ response is greater for receptors containing NK1 receptor C-terminal cytoplasmic region}

In previous work on the NK1 receptor (Sugiya et al., 1988) and the $m_{3}$-muscarinic receptor (Tobin et al., 1992), reduction of the amplitude of the peak $\mathrm{I}(1,4,5) \mathrm{P}_{3}$ response in cells preexposed to agonist was used as a measure of desensitization. Because the peak response occurred at $10 \mathrm{~s}$ of stimulation in all of the cell lines, levels of $\mathrm{I}(1,4,5) \mathrm{P}_{3}$ were determined at this time of stimulation. Neurokinin at $1 \mu M$ was used to desensitize cells to compare cell lines under similar conditions of complete receptor occupancy over the 1min interval used to desensitize cells and to insure that all relevant pathways of homologous desensitization were activated for each cell line. For measuring the reduction in the maximal response following desensitization, $10 \mu M$ neurokinin was used for the challenging exposure to control and desensitized cells. This agonist concentration maximally stimulated both control and desensitized cells for each cell line (data not shown), allowing the comparison of the cell lines at similar points on their dose-response curves. Figure 3 indicates that the receptor constructs containing the $\mathrm{C}$ terminal cytoplasmic region of the NK 1 receptor desensitized significantly more than those containing the C-terminal region of the NK2 receptor. The NK1 receptor was determined to desensitize to the same extent using a $100 \mathrm{n} M, 1-\mathrm{min}$ exposure to substance $\mathrm{P}$ (data not shown).

\section{CHO NK1 $I(1,4,5) P_{3}$ response recovery}

Recovery of the $\mathrm{I}(1,4,5) \mathrm{P}_{3}$ response was characterized for the strongly desensitizing $\mathrm{CHO} \mathrm{NK} l$ cell line (Fig. 4). The recovery of the $I(1,4,5) \mathrm{P}_{3}$ response appeared to be close to linear from 5 to $30 \mathrm{~min}$, recovering from $28 \%$ of control values at $5 \mathrm{~min}$ of recovery to $78 \%$ of control values after $30 \mathrm{~min}$ of recovery. After recovery for $2 \mathrm{~h}$ at $37^{\circ} \mathrm{C}$, the $\mathrm{I}(1,4,5) \mathrm{P}_{3}$ response of $\mathrm{CHO}$ NK1 had returned to $100 \%$ of control values.

\section{Measurement of receptor internalization}

To determine the contribution of receptor internalization to the desensitization observed in Fig. 3, receptor internalization was characterized by labeling cells with ${ }^{125}$ I-radiolabeled neurokinins and using an acid wash to remove surface-bound neurokinin (Fig. 5). Two features of these experiments are of note: (a) Each cell line rapidly internalized radiolabeled neurokinin, with $\sim 75-80 \%$ of radiolabeled neurokinin internalized after $10 \mathrm{~min}$ at $37^{\circ} \mathrm{C}$ for each cell line. (b)

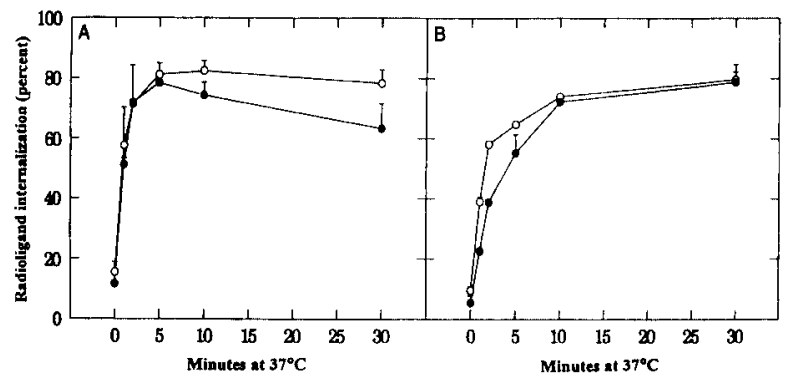

FIG. 5. Receptor internalization of $\mathrm{CHO}$ neurokinin cell lines. Cells were allowed to bind $0.3 n M$ radiolabeled neurokinin $\left[{ }^{125}\right.$ substance $\mathrm{P}(\mathbf{A})$ for $\mathrm{CHO} N \mathrm{NK}_{1}(\mathrm{O})$ and $\mathrm{CHO}$ NK1NK2 $(\bullet)$ and ${ }^{125} \mathrm{I}$-neurokinin $\mathrm{A}(\mathrm{B})$ for CHO NK2 (O) and CHO NK2NK1 (•)] for $90 \mathrm{~min}$ in the cold and then shifted to $37^{\circ} \mathrm{C}$ for various intervals as shown. Assays were processed, and internalization was quantified, as described in Materials and Methods. Nonspecific binding was determined in the presence of $1 \mu M$ substance $\mathrm{P}$ ( $\mathrm{CHO}$ NK1 and $\mathrm{CHO}$ NK1NK2) or $1 \mu \mathrm{M}$ neurokinin $\mathrm{A}$ (CHO NK2 and $\mathrm{CHO}$ NK2NK1). Data are mean \pm SEM (bars) values from three independent experiments done in quadruplicate for $\mathrm{CHO}$ NK1 and $\mathrm{CHO}$ NK1NK2 and mean \pm ranges (bars) values from two independent experiments done in quadruplicate for $\mathrm{CHO}$ NK2 and CHO NK2NK1. 


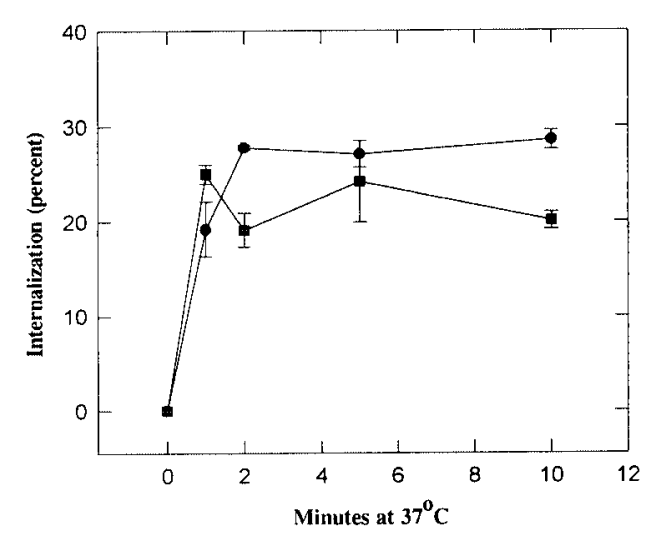

FIG. 6. Loss of receptor surface sites for cell lines $\mathrm{CHO} N K 1$

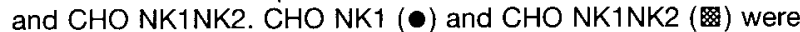
exposed to $1 \mu M$ substance $P$ for the times indicated. Internalization was quenched by adding 5 volumes of ice-cold DMEM/F12 and immediately placing cells on ice. Cells were then rinsed as described in desensitization experiments, and binding to whole cells was determined on ice as described in Materials and Methods. Percent loss of receptor surface sites was quantified as [1

- (specific binding at time $x /$ specific binding at time 0$)] \times 100$. Data are mean \pm ranges (bars) values from two experiments performed in parallel. Binding assays to determine loss of receptor surface sites were done in quadruplicate.

There is no obvious correlation between the extent of receptor internalization and receptor desensitization. In cell lines $\mathrm{CHO}$ NK1 and CHO NK2NK1, the proportion of receptors internalized after $1 \mathrm{~min}$ (the interval used to desensitize cells) was less than the percent desensitization of the $I(1,4,5) \mathrm{P}_{3}$ response, whereas in cell lines CHO NK2 and CHO NK1NK2, the proportion of receptors internalized after $1 \mathrm{~min}$ was greater than the percent desensitization of the $I(1,4,5) \mathrm{P}_{3}$ response.

To measure internalization under conditions more comparable to those used for desensitization, receptor internalization was measured for cell lines CHO NK1 and CHO NK1NK2 by measuring loss of receptor surface sites resulting from exposure of cells to $1 \mu M$ substance P (Fig. 6). Three features of these experiments are of note: (a) The percentage of receptors internalized as measured by this method is much less than the percentage of receptors internalized as measured by the method described in Fig. 5. (b) Both cell lines underwent a rapid loss of receptor surface sites, with an $\sim 20 \%$ loss of receptor surface sites after a 1 min exposure to substance $P$ for each cell line. (c) There is no correlation between the extent of the loss of receptor surface sites and of desensitization. Although the loss of receptor surface sites from $\mathrm{CHO}$ $\mathrm{NK} 1$ is slightly greater than that from cell line $\mathrm{CHO}$ NK1NK2, this difference is far less than the difference in desensitization between the two cell lines.

\section{Inhibition of CHO NK1 internalization does not inhibit desensitization}

To examine further the relationship between receptor internalization and desensitization, the effect of two internalization inhibitors, the disulfide cross-linker phenylarsine oxide (Hertel et al., 1985) and hyperosmolar sucrose (Daukas and Zigmond, 1985) [ an inhibitor of clathrin-coated pit formation (Heuser and Anderson, 1989)], on desensitization of the CHO NK1 cell line was examined (Fig. 7). Pretreatment with 25 $\mu M$ phenylarsine oxide inhibited loss of CHO NK1 receptor surface sites by $\sim 50 \%$, although this inhibition was only significant at $p<0.1$, whereas pretreatment with $300 \mathrm{~m} M$ hyperosmolar sucrose significantly inhibited loss of receptor surface sites by $\sim 60 \%$. When cells were labeled with ${ }^{125} \mathrm{I}$-substance $\mathrm{P}$, both inhibitors significantly and potently inhibited internalization of radiolabeled substance $\mathrm{P}$ when cells were shifted to $37^{\circ} \mathrm{C}$ (data not shown). Neither treatment, however, inhibited CHO NK1 desensitization.

\section{Inhibition of protein kinases does not inhibit desensitization}

Because the C-terminal cytoplasmic region of the NK1 receptor contains more potential phosphorylation sites for serine-threonine protein kinases than the NK2 receptor, the effect of serine-threonine kinase inhibitors on the desensitization of the NK1 receptor was examined. Pretreatment with $1 \mu M$ Ro 31-8220 [a selective protein kinase C (PKC) inhibitor (Davis et al.,

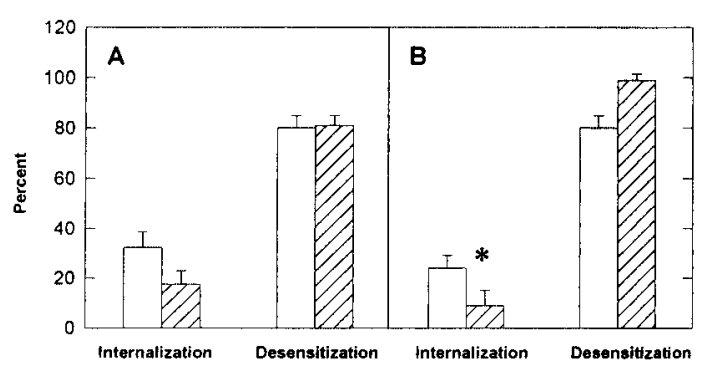

FIG. 7. Effect of (A) phenylarsine oxide and (B) hyperosmolar sucrose on $\mathrm{CHO}$ NK 1 internalization and desensitization. A: Cells $\left(1 \times 10^{7} / \mathrm{ml}\right)$ were treated with $25 \mu M$ phenylarsine oxide in

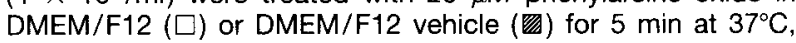
rinsed three times with buffer, and then allowed to recover for $45 \mathrm{~min}$ at $37^{\circ} \mathrm{C}$. B: Cells were treated with $0.3 \mathrm{M}$ sucrose in DMEM/F12 ( $\square$ ) or DMEM/F12 vehicle (ש) for $30 \mathrm{~min}$ at $37^{\circ} \mathrm{C}$. For treated cells, $0.3 \mathrm{M}$ sucrose was present through all subsequent steps of the experiment. For measurement of internalization, cells were exposed to $1 \mu \mathrm{M}$ substance $\mathrm{P}$ or DMEM/F12 vehicle for $5 \mathrm{~min}$ in the presence or absence of inhibitor. Internalization was then measured as described in Materials and Methods. Desensitization was measured, and $I(1,4,5) P_{3}$ levels were determined, as described in Materials and Methods. Measurement of inhibition of internalization was done three times for each inhibitor, with binding assays done in quadruplicate. Data for the effect of phenylarsine oxide on desensitization are mean \pm ranges (bars) values from two experiments done in quintuplicate. Data for the effect of sucrose on desensitization are mean \pm SEM (bars) values from three experiments done in quintuplicate. For internalization measurements, "percent" refers to percent loss of receptor surface sites, as in Fig. 6; for desensitization measurements, "percent" refers to percent desensitization of the $\mathrm{I}(1,4,5) \mathrm{P}_{3}$ response, as in Fig. 3 . In $\mathrm{B}$, hyperosmolar sucrose significantly inhibits NK1 receptor internalization compared with the control: * $p<0.05$ by paired two-tailed $t$ test. 


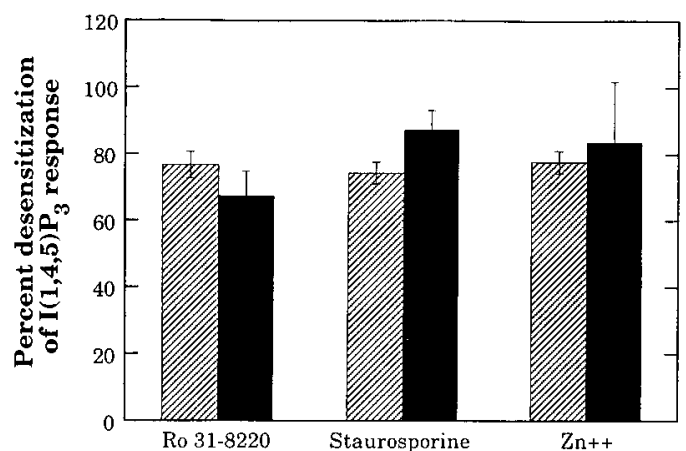

FIG. 8. Effect of protein kinase inhibitors on CHO NK1 desensitization. $\mathrm{CHO}$ NK1 cells were pretreated with $1 \mu M$ Ro 31-8220 $\left(10 \mathrm{~min}, 37^{\circ} \mathrm{C}\right), 1 \mu \mathrm{M}$ staurosporine $\left(10 \mathrm{~min}, 37^{\circ} \mathrm{C}\right)$, or $1 \mathrm{mM}$ $\mathrm{Zn}^{2} \cdot\left(15 \mathrm{~min}, 37^{\circ} \mathrm{C}\right.$ ) in DMEM/F12 ( $)$ or DMEM/F12 vehicle (controls for each treatment; 怔). Desensitization was determined as described in Materials and Methods. For cells treated with Ro $31-8220$ or staurosporine, the inhibiting agent was present throughout the experiment. The continued presence of $\mathrm{Zn}^{2+}$ throughout the cold rinse was toxic to the treated cells, so $1 \mathrm{mM}$ $\mathrm{Zn}^{2+}$ was added back to the treated cells immediately before the 5 -min recovery at $37^{\circ} \mathrm{C}$. For each inhibitor, data are mean \pm SEM (bars) values from three experiments done in quintuplicate.

1989)], I $\mu M$ staurosporine [an inhibitor of cyclic AMP-dependent protein kinase, cyclic GMP-dependent protein kinase, calcium/calmodulin-dependent protein kinase II, and PKC but not of calcium/calmodulin kinase III, casein kinase 1, and casein kinase 2 (Rüegg and Burgess, 1989; Geschwendt et al., 1994; Meggio et al., 1995)], or $1 \mathrm{~m} M \mathrm{Zn}^{2+}[$ an inhibitor of $\mathrm{G}$ protein receptor kinase (GRK) 2 in vitro (Benovic et al., 1987) and an inhibitor of 5-hydroxytryptamine ${ }_{4}$ receptor desensitization in colliculi neurons in vivo (Ansanay et al., 1992)] had no effect on desensitization of the NKI receptor (Fig. 8).

\section{DISCUSSION}

The present study investigates the extent of involvement of the C-terminal cytoplasmic region of the NKI receptor in its desensitization and examines whether receptor internalization or phosphorylation by serinethreonine protein kinases plays a role in this desensitization. For $\mathrm{G}$ protein-coupled receptors that activate phosphoinositide hydrolysis by phosphoinositide-specific phospholipase C (PIC), several methodologies and parameters have been used to measure desensitization (reviewed by Fisher, 1995). Some investigators have defined desensitization as the return to basal levels of $I(1,4,5) P_{3}$ after an initial rapid peak response that is commonly observed for receptors coupled to this pathway (Schleicher et al., 1993; Takano et al., 1994). Other investigators have characterized desensitization as the decline in the $\mathrm{I}(1,4,5) \mathrm{P}_{3}$ peak response in cells preexposed to agonist (Sugiya et al., 1988; Tobin et al., 1992). In some cases desensitization of this pathway has been determined by characterizing the rate of accumulation of ${ }^{3} \mathrm{H}$-inositol monophosphates in $\left[{ }^{3} \mathrm{H}\right]$ inositol-prelabeled cells (Thompson and Fisher, 1990; Barr and Watson, 1994). In the experiments described here, desensitization was characterized by examining the production of $\mathrm{I}(1,4,5) \mathrm{P}_{3}$, because this second messenger lies at an early point in the activation of the inositol phosphate pathway and is known to have an important physiological effect in the cell, stimulating $\mathrm{Ca}^{2+}$ release by binding to the $\mathrm{I}(1,4,5) \mathrm{P}_{3}$ receptor of the endoplasmic reticulum (Streb et al., 1983 ).

\section{$I(1,4,5) P_{3}$ response of neurokinin receptors}

The pattern of $\mathrm{I}(1,4,5) \mathrm{P}_{3}$ formation (Fig. 2 ) for all four cell lines was qualitatively similar, although the amplitude of the peak response was greater for $\mathrm{CHO}$ NK1NK2 than for the other three cell lines. Whether this is the result of reduced desensitization or enhanced coupling compared with the other three cell lines is difficult to determine from these experiments. The fact that for all four cell lines ${ }^{3} \mathrm{H}$-inositol phosphates continued to accumulate out to $\sim 30 \mathrm{~min}$ in $\mathrm{Li}^{+}$-treated $\left[{ }^{3} \mathrm{H}\right]$ inositol-prelabeled cells indicated that $\mathrm{I}(1,4,5) \mathrm{P}_{3}$ was still being produced after $1 \mathrm{~min}$ and that for this system the return to basal levels of the $I(1,4,5) P_{3}$ response was not an appropriate measure of desensitization. One possible explanation for this observation of continued $I(1,4,5) \mathrm{P}_{3}$ production, but a return to near basal cellular content of $\mathrm{I}(1,4,5) \mathrm{P}_{3}$, is that the rate of production of $\mathrm{I}(1,4,5) \mathrm{P}_{3}$ and the rate of metabolism of $I(1,4,5) P_{3}$ to other inositol phosphates are roughly similar after $1 \mathrm{~min}$, resulting in levels of $\mathrm{I}(1,4,5) \mathrm{P}_{3}$ close to baseline (Fisher, 1995).

\section{Regions of neurokinin receptors involved in desensitization}

Results in Fig. 3 comparing the NK1, NK2, and their $\mathrm{C}$-terminal chimeric receptors indicate a role for the C-terminal region of the NK1 receptor in desensitization of the $\mathrm{I}(1,4,5) \mathrm{P}_{3}$ response, because the receptors containing the NK1 receptor $\mathrm{C}$-terminal region (NK1 and NK2NK1) desensitized significantly more than the corresponding receptors containing the NK2 receptor C-terminal region (NK1NK2 and NK2). Sasakawa et al. (1994a) demonstrated in the Xenopus oocyte expression system that deletion of a portion of the C-terminal region of the rat NK1 receptor (from amino acids 338 to 360 ) attenuates desensitization of $\mathrm{Ca}^{2+}$-induced $\mathrm{Cl}^{-}$flux. Our results demonstrate that this region of the receptor is capable of conferring desensitization of the $\mathrm{I}(1,4,5) \mathrm{P}_{3}$ response when transferred to the weakly desensitizing rat NK2 receptor, demonstrating positively that determinants of agonistmediated desensitization are located within the C-terminal region of the NK1 receptor.

Cyr et al. (1993), in Xenopus oocytes (measuring membrane depolarization), Josiah et al. (1994), in transfected CHO cells (measuring the $\mathrm{Ca}^{2+}$ release), and Alblas et al. (1995) in transfected LT11 cells (measuring the inositol phosphate response in $\left[{ }^{3} \mathrm{H}\right]$ - 
inositol-prelabeled cells), observed much stronger desensitization of the human NK2 receptor than what was observed for the rat NK2 receptor in Xenopus (Nakanishi et al., 1990) and than what was observed for the rat NK2 receptor in transfected $\mathrm{CHO}$ cells in the present work. Alblas et al. (1995) found that a Cterminally truncated form of the human NK2 receptor fails to desensitize and has reduced phosphorylation by $\mathrm{PKC}$ compared with the wild-type receptor, indicating a role for PKC phosphorylation of the C-terminal cytoplasmic region in desensitization. In this regard, it is of interest to note that the human and rat NK2 receptors diverge considerably ( 23 of 60 amino acids; the human receptor also contains an additional nine amino acids at the end of the cytoplasmic tail) after the putative palmitoylation site in the C-terminal cytoplasmic region, including several serines and threonines present in the human receptor but not the rat receptor that could serve as phosphorylation sites. The two receptors, however, have not been directly compared in the same cell system, making it difficult to determine the actual magnitude of the differences in desensitization of the human and rat NK2 receptors.

\section{Role of lipid substrate depletion in desensitization}

Because phosphatidylinositol 4,5-bisphosphate, the substrate hydrolyzed by PIC to form $\mathrm{I}(1,4,5) \mathrm{P}_{3}$ and diacylglycerol, constitutes $<5 \%$ of the cellular inositol lipid pool, it would be rapidly depleted in most agoniststimulated cells in the vicinity of the PIC even if replaced by resynthesis. The availability of this substrate therefore represents a potential point of regulation in the response of receptors coupled to PIC (Fisher, 1995 ). Lipid substrate depletion, however, seems an unlikely explanation for the differences in desensitization between cell lines observed in Fig. 3 because the cell lines that desensitized less (NK2 and NK1NK2) had comparable or greater initial $\mathrm{I}(1,4,5) \mathrm{P}_{3}$ responses than the corresponding more strongly desensitizing cell lines (NK2NK1 and NK1).

\section{Role of receptor internalization in NK1 receptor desensitization}

Based on previous observations of rapid agonistmediated NK1 receptor internalization in vivo (Bowden et al., 1994; Mantyh et al., 1995a,b), in isolated rat parotid acinar cells (Sugiya et al., 1988), and in transfected epithelial cells (Garland et al., 1994), receptor internalization has been proposed as a potential mechanism of desensitization for this receptor. The extent of involvement of receptor internalization in desensitization has been found to vary depending on the receptor and cell type. For the $\beta_{2}$-adrenergic receptor, receptor internalization plays at least a partial role in desensitization in some cell types, such as A431 cells (Lohse et al., 1990), but not in other cell types, such as transfected CHO cells (Yu et al., 1993; Barak et al., 1994). In A431 cells cyclic AMP-dependent protein kinase and GRK-mediated desensitization ( $t_{1 / 2}$ values of 0.25 and $3 \mathrm{~min}$, respectively) occurs at a faster rate than receptor internalization $\left(t_{1 / 2}\right.$ of 10 $\min )$, suggesting that for short $(<5$-min $)$ agonist exposures internalization is not responsible for the majority of desensitization (Roth et al., 1991). In CHO cells transfected with the $\beta_{2}$-adrenergic receptor, agents [ $\mathrm{su}$ crose and concanavalin A (Yu et al., 1993)] or mutations (Barak et al., 1994) that prevent receptor internalization do not interfere with receptor desensitization. In $\mathrm{CHO}$ cells transfected with the $\mathrm{m}_{3}$-muscarinic receptor, the separation between receptor desensitization and receptor internalization is more obvious: $50 \%$ desensitization of the $\mathrm{I}(1,4,5) \mathrm{P}_{3}$ response is observed after a 5-min agonist pretreatment, whereas receptor internalization is not significant until $15 \mathrm{~min}$ of agonist exposure, when there is a $10 \%$ loss of surface binding sites (Tobin et al., 1992).

Characterization of receptor internalization using both radiolabeled neurokinins and measurement of the loss of receptor surface sites in the system described here with cells expressing similar numbers of receptors did not indicate any relationship between receptor internalization and short-term desensitization: The four cell lines had similar rates of internalization as measured by internalization of radiolabeled neurokinins, and the CHO NK1 and CHO NK1NK2 cell lines had similar rates of loss of receptor surface sites. For the CHO NK1 cell line, both methods indicate that the percentage of receptors internalized after $1 \mathrm{~min}$ is much less than the percent desensitization of the $\mathrm{I}(1,4,5) \mathrm{P}_{3}$ response, indicating that for this cell line desensitization of the $\mathrm{I}(1,4,5) \mathrm{P}_{3}$ response precedes receptor internalization. Two inhibitors of NK 1 receptor internalization, phenylarsine oxide and hyperosmolar sucrose, did not inhibit NKl receptor desensitization in the stably transfected $\mathrm{CHO} \mathrm{KI}$ cells investigated here, further demonstrating that short-term desensitization of this receptor is not mediated by internalization in this system. In a different cell type, isolated rat parotid acinar cells, desensitization of the $\mathrm{I}(1,4,5) \mathrm{P}_{3}$ response and loss of receptor surface sites more closely parallel each other than in the system described in this article (Sugiya et al., 1988). The contribution of receptor internalization to desensitization in this cell type, however, has not been determined.

For CHO NK1 and CHO NK1NK2 the percentage of receptors internalized as measured by loss of receptor surface sites (Fig. 6) is much less than the percentage of receptors internalized as measured by internalization of the ${ }^{125}$ I-radiolabeled neurokinins in the work described herein (Fig. 5) and by other investigators (Garland et al., 1994). The explanation for this is not known, but it is possible that the low concentration of ${ }^{125}$ I-radiolabeled neurokinins labels a population of high-affinity sites that are preferentially internalized compared with the receptor population as a whole. It is also possible that the lower percent internalization in Fig. 6 is the result of engaging the entire receptor population rather than a portion of the receptor population as in Fig. 5. The internalization machinery of the 
cell may be saturated in the experiment described in Fig. 6, and thus a lower percentage of bound receptors is internalized. Regardless, cell lines $\mathrm{CHO} \mathrm{NK} 1$ and CHO NK1NK2 have similar internalization rates whichever method is used.

\section{Role of serine-threonine kinases in NK1 receptor desensitization}

Desensitization of many $G$ protein-coupled receptors is known to be mediated via phosphorylation by various serine-threonine kinases, including PKC, cyclic AMP-dependent protein kinase, and members of the GRK family. Several recent observations have indicated a possible role for serine-threonine kinases in NK1 receptor desensitization: (a) Purified rat NK1 receptor reconstituted into lipid vesicles undergoes agonist-dependent phosphorylation by GRK 2 and GRK 3 (Kwatra et al., 1993). (b) Polyanions (inositol pentakisphosphate and inositol hexakisphosphate) that bind to arrestin (an essential component of the GRKmediated desensitization pathway) inhibit desensitization of the rat NK1 receptor when injected into Xenopus oocytes expressing this receptor (Sasakawa et al., $1994 b$ ). (c) The region of the rat NK1 receptor that when deleted leads to attenuation of desensitization of this receptor contains 10 serines and threonines (Sasakawa et al., 1994a). As the number of serines and threonines in the $\mathrm{NK} 1$ receptor $\mathrm{C}$-terminal region is greater than the number in the NK2 receptor C-terminal region, the results with the chimeric neurokinin receptors (Fig. 3) are consistent with a role for serinethreonine kinases in desensitization. Several kinase inhibitors, however, including $1 \mathrm{~m} M \mathrm{Zn}^{2+}$, Ro 31-8220, and staurosporine, had no effect on desensitization of the NK1 receptor in the CHO NK1 cells used here (Fig. 8). The failure of Ro 31-8220 to inhibit shortterm desensitization of the NK1 receptor in transfected CHO cells is consistent with observations that PKC inhibition has no effect on short-term $(<5$-min agonist exposure ) NK1 receptor desensitization in rat parotid acinar cells (Sugiya et al., 1987) and transfected UC11 cells (Barr and Watson, 1994). The failure of $\mathrm{Zn}^{2+}$ to inhibit desensitization, however, does not exclude a role for GRKs in desensitization of the NK1 receptor in $\mathrm{CHO}$ cells, because it has not been demonstrated that $\mathrm{Zn}^{2+}$ inhibits GRKs in vivo in all systems.

In regard to the results in Fig. 8, it is of interest to note that the $\mathrm{m}_{3}$-muscarinic receptor, another rapidly desensitizing $G$ protein-coupled receptor that stimulates inositol phosphate formation (Tobin et al., 1992), undergoes agonist-dependent phosphorylation in $\mathrm{CHO}$ cells (Tobin and Nahorski, 1993) by a kinase, termed muscarinic receptor kinase, that is distinct from previously characterized second-messenger regulated kinases and GRKs (Tobin et al., 1996). It is also of interest that this receptor is phosphorylated by purified GRK 2 in membrane preparations from transfected Spodoptera frugiperda 9 cells (DebBurman et al., 1995 ) but is not phosphorylated by this kinase in CHO $\mathrm{m}_{3}$ broken-cell preparations (Tobin et al., 1993), indicating that observations of receptor phosphorylation by GRK 2 in one system may not necessarily be applicable to another.

In summary, the rat NK1, NK2, and two chimeric receptors in which the $\mathrm{C}$-terminal cytoplasmic region was exchanged were expressed in CHO cells. Desensitization of the $\mathrm{I}(1,4,5) \mathrm{P}_{3}$ response was significantly greater for receptors containing the NK1 receptor Cterminal cytoplasmic region, indicating a role for this region of the receptor in desensitization. Desensitization of the NK1 receptor $\mathrm{I}(1,4,5) \mathrm{P}_{3}$ response preceded NK1 receptor internalization, there was no relationship among the four receptors between the degree of receptor internalization and desensitization, and inhibitors of NK1 receptor internalization had no effect on its desensitization, demonstrating that short-term desensitization of the NK1 receptor $\mathrm{I}(1,4,5) \mathrm{P}_{3}$ response was not mediated by receptor internalization. Inhibitors of PKC, cyclic AMP-dependent protein kinase, calcium/ calmodulin-dependent protein kinase II, and GRK 2 had no effect on desensitization of the NK1 receptor, indicating that short-term desensitization of the NK1 receptor in the system described here was not mediated by these kinases.

Acknowledgment: The authors wish to thank Dr. Shigetada Nakanishi for generously supplying neurokinin receptor cDNA clones, Dr. Stephen Fisher for technical advice on the measurements of $\mathrm{I}(1,4,5) \mathrm{P}_{3}$ and other assays and helpful comments on the manuscript, Drs. Richard Hume and Ruthann Nichols for manuscript comments, and many colleagues at Parke-Davis for technical advice.

\section{REFERENCES}

Aharoney D., Little J., Thomas T., Powell S., Berry D., and Graham A. (1995) Isolation and pharmacological characterization of a hamster urinary bladder neurokinin A receptor cDNA. $M o l$. Pharmacol. 45, 9-19.

Alblas J., van Etten I., Khanum A., and Moolenaar W. H. (1995) C-terminal truncation of the neurokinin-2 receptor causes enhanced and sustained agonist-induced signaling. J. Biol. Chem. 270, 8944-8951.

Ansanay H., Sebben M., Bockaert J., and Dumas A. (1992) Characterization of homologous 5-hydroxytryptamine ${ }_{4}$ receptor desensitization in colliculi neurons. Mol. Pharmacol. 42, 808-816.

Barak L. S., Tiberi M., Freedman N. J., Kwatra M. M., Lefkowitz R. J., and Caron M. G. (1994) A highly conserved tyrosine residue in $\mathrm{G}$ protein-coupled receptors is required for agonistmediated $\beta_{2}$-adrenergic receptor sequestration. J. Biol. Chem. 269, 2790-2795

Barr A. J. and Watson S. P. (1994) Protein kinase C mediates delayed inhibitory feedback regulation of human neurokinin type 1 receptor activation of phospholipase $C$ in UC11 astrocytoma cells. Mol. Pharmacol. 46, 266-273.

Benovic J. L., Mayor F. Jr., Staniszewski C., Lefkowitz R. J., and Caron M. G. (1987) Purification and characterization of the $\beta$ adrenergic receptor kinase. J. Biol. Chem. 262, 9026-9032.

Benovic J. L., Stone W. C., Caron M. G., and Lefkowitz R. J. (1989) Inhibition of the $\beta$-adrenergic receptor kinase by polyanions. J. Biol. Chem. 264, 6707-6710.

Blount P. and Krause J. E. (1993) Functional nonequivalence of structurally homologous domains of neurokinin-1 and neuroki- 
nin-2 type tachykinin receptors. J. Biol. Chem. 268, $16388-$ 16395.

Bowden J. J., Garland A. M., Baluk P., Lefevre P., Grady E. F., Vigna S. R., Bunnett N. W., and McDonald D. M. (1994) Direct observation of substance P-induced internalization of neurokinin 1 (NK1) receptors at sites of inflammation. Proc. Natl. Acad. Sci. USA 91, 8964-8968.

Bredt D. S., Mourey R. J., and Snyder S. H. (1989) A simple, sensitive, and specific radioreceptor assay for inositol 1,4,5trisphosphate in biological tissues. Biochem. Biophys. Res. Commun. 159, 976-982.

Chuang T. T., Sallese M., Ambrosoni G., Parruti G., and De Blasi A. (1992) High expression of $\beta$-adrenergic receptor kinase in human peripheral blood leukocytes. J. Biol. Chem. 267, 68866892.

Cyr C. R., Rudy B., and Kris R. M. (1993) Prolonged desensitization of the human endothelin A receptor in Xenopus oocytes. $J$. Biol. Chem. 268, 26071-26074.

Daukas G. and Zigmond S. H. (1985) Inhibition of receptor-mediated but not fluid-phase endocytosis in polymorphonuclear leukocytes. J. Cell Biol. 101, 1673-1679.

Davis P. D., Hill C. H., Keech E., Lawton G., Nixon J. S., Sedgwick A., Wadsworth J., Westmacott D., and Wilkinson S. E. (1989) Potent selective inhibitors of protein kinase C. FEBS Lett. 259 $61-63$.

DebBurman S. K., Kunapuli P., Benovic J. L., and Hosey M. M. (1995) Agonist-dependent phosphorylation of human muscarinic receptors in Spodoptera frugiperda insect cell membranes by G-protein receptor kinases. Mol. Pharmacol. 47, 224-233.

Fisher S. K. (1995) Homologous and heterologous regulation of receptor-stimulated phosphoinositide hydrolysis. Eur. J. Pharmacol. 288, 231-250.

Garland A. M., Grady E. F., Payan D. G., Vigna S. R., and Bunnett N. W. (1994) Agonist-induced internalization of the substance $\mathrm{P}(\mathrm{NK} 1)$ receptor expressed in epithelial cells. Biochem. J. 303, $177-186$.

Geschwendt M., Kittstein W., and Marks F. (1994) Elongation factor-2 kinase: effective inhibition by the novel protein kinase inhibitor rottlerin and relative insensitivity towards staurosporine. FEBS Lett. 338, 85-88.

Hershey A. D. and Krause J. E. (1990) Molecular characterization of a functional cDNA encoding the rat substance $P$ receptor Science 247, 958-962.

Hertel C., Coulter S. J., and Perkins J. P. (1985) A comparison of catecholamine-induced internalization of beta-adrenergic receptors and receptor-mediated endocytosis of epidermal growth factor in human astrocytoma cells. Inhibition by phenylarsine oxide. J. Biol. Chem. 260, 12547-12553.

Heuser J. E. and Anderson R. G. (1989) Hypertonic media inhibit receptor-mediated endocytosis by blocking clathrin-coated pit formation. J. Cell Biol. 108, 389-400.

Josiah S. M., Cyr C. R., Chu V., Grumet M., Gardner J. P., and Kris R. M. (1994) Regions of the human neurokinin A receptor involved in the generation of second messengers and in receptor desensitization. Biochem. Biophys. Res. Commun. 199, 626632.

Krause J. E., Blount P., and Sachais B. S. (1994) Molecular biology of receptors: structure, expression, and regulatory mechanisms, in The Tachykinin Receptors (Buck S. H., ed), pp. 165-218. Humana Press, Totowa, New Jersey.

Kwatra M. M., Schwinn D. A., Schreurs J., Blank J. L., Kim C., Benovic J. B., Krause J. E., Caron M. G., and Lefkowitz R. J. (1993) The substance $P$ receptor, which couples to $G q / 11$, is a substrate of $\beta$-adrenergic receptor kinases 1 and 2. J. Biol. Chem. 268, 9161-9164.

Lohse M. J., Benovic J. L., Caron M. G., and Lefkowitz R. J. (1990) Multiple pathways of rapid $\beta_{2}$-adrenergic receptor desensitization. J. Biol. Chem. 265, 3202-3209.

Mantyh P. W., Allen C. J., Ghilardi J. R., Rogers S. D., Mantyh C. R., Liu H., Basbaum A. I., Vigna S. R., and Maggio J. E. (1995a) Rapid endocytosis of a $G$ protein-coupled receptor: substance P-evoked internalization of this receptor in the rat striatum in vivo. Proc. Natl. Acad. Sci. USA 92, 2622-2626.

Mantyh P. W., DeMaster E., Malhotra A., Ghilardi J. R., Rogers S. D., Mantyh C. R., Liu H. Basbaum A. I., Vigna S. R., Maggio J. E., and Simone D. A. (1995b) Receptor endocytosis and dendrite reshaping in spinal neurons after somatosensory stimulation. Science 268, 1629-1632.

Masu Y., Nakayama, K., Tamaki H., Harada Y., Kuno M., and Nakanishi S. (1987) cDNA cloning of bovine substance-K receptor through oocyte expression system. Nature 329, 836838.

McLean S. and Lowe J. A. III (1994) Agonist and antagonist receptor binding, in ,The Tachykinin Receptors (Buck S. H., ed), pp. 67-99. Humana Press, Totowa, New Jersey.

Meggio F., Donella Deana A., Ruzzene M., Brunati A. M., Cesaro L., Guerra B., Meyer T., Mett H., Fabbro D., Furet P., Dobrowolska G., and Pinna L. A. (1995) Different susceptibility of protein kinases to staurosporine inhibition: kinetic studies and molecular bases for the resistance of protein kinase CK2. FEBS Lett. 234, 317-322.

Nakanishi S., Ohkubo H., Kakizuka A., Yokota Y., Shigemoto R. Sasai Y., and Takumi T. (1990) Molecular characterization of mammalian tachykinin receptors and a possible epithelial potassium channel. Recent Prog. Horm. Res. 46, 59-84.

Ohkubo H. and Nakanishi S. (1991) Molecular characterization of the three tachykinin receptors. Ann. NY Acad. Sci. 632, 53-62.

Pei G., Tiberi T., Caron M. G., and Lefkowitz R. J. (1994) An approach to the study of G-protein-coupled receptor kinases: an in vitro-purified membrane assay reveals differential receptor specificity and regulation by $\mathrm{G}_{\beta \gamma}$ subunits. Proc. Natl. Acad. Sci. USA 91, 3633-3636.

Pippig S., Andexinger S., Daniel K., Puzicha M., Caron M. G., Lefkowitz R. J., and Lohse M. J. (1993) Overexpression of $\beta$ arrestin and $\beta$-adrenergic receptor kinase augments desensitization of $\beta_{2}$-adrenergic receptors. J. Biol. Chem. 268, 3201-3208

Roth N., Campbell P. T., Caron M. G., Lefkowitz R. J., and Lohse M. J. ( 1991 ) Comparative rates of desensitization of $\beta$-adrenergic receptors by the $\beta$-adrenergic receptor kinase and the cAMPdependent protein kinase. Proc. Natl. Acad. Sci. USA 88, 62016204 .

Rüegg U. T. and Burgess G. M. (1989) Staurosporine, K-252 and UCN-01: potent but nonspecific inhibitors of protein kinases. Trends Pharmacol. Sci. 10, 218-220.

Sasakawa N., Sharif M., and Hanley M. R. (1994a) Attenuation of agonist-induced desensitization of the rat substance $P$ receptor by progressive truncation of the C-terminus. FEBS Lett. 347, $181-184$.

Sasakawa N., Ferguson J. E., Sharif M., and Hanley M. R. (1994b) Attenuation of agonist-induced desensitization of the rat substance $\mathbf{P}$ receptor by microinjection of inositol pentakis- and hexakisphosphates in Xenopus laevis oocytes. Mol. Pharmacol. 46, 380-385.

Schleicher S., Boekhoff I., Arriza J., Lefkowitz R. J., and Breer H. (1993) A $\beta$-adrenergic receptor kinase-like enzyme is involved in olfactory signal termination. Proc. Natl. Acad. Sci. USA 90, $1420-1424$.

Shigemoto R., Yoshifumi Y., Tsuchida K., and Nakanishi S. (1990) Cloning and expression of a rat neuromedin $\mathrm{K}$ receptor $\mathrm{cDNA}$ J. Biol. Chem. 265, 623-628.

Streb H., Irvine R. F., Berridge M. J., and Schulz I. ( 1983) Release of $\mathrm{Ca}^{2+}$ from a nonmitochondrial intracellular store in pancreatic acinar cells by inositol-1,4,5-trisphosphate. Nature 306, 67-69.

Sugiya H., Tennes K. A., and Putney J. W. Jr. (1987) Homologous desensitization of substance-P-induced inositol polyphosphate formation in rat parotid acinar cells. Biochem. J. 244, 647-653.

Sugiya H., Obie J. F., and Putney J. W. Jr. (1988) Two modes of regulation of the phospholipase $\mathrm{C}$-linked substance-P receptor in rat parotid acinar cells. Biochem. J. 253, 439-446.

Takano T. Honda Z.-i., Sakanaka C. Izumi T., Kameyama K. Haga K., Haga T., Kurokawa K., and Shimizu S. (1994) Role of cytoplasmic tail phosphorylation sites of platelet-activating fac- 
tor receptor in agonist-induced desensitization. J. Biol. Chem. 269, 22453-22458.

Thompson A. K. and Fisher S. K. (1990) Relationship between agonist-induced muscarinic receptor loss and desensitization of stimulated phosphoinositide turnover in two neuroblastomas: methodological considerations. J. Pharmacol. Exp. Ther. 252, $744-752$.

Tobin A. B. and Nahorski S. R. (1993) Rapid agonist-mediated phosphorylation of $\mathrm{m}_{3}$-muscarinic receptors revealed by immunoprecipitation. J. Biol. Chem. 268, 9817-9823.

Tobin A. B., Lambert D. G., and Nahorski S. R. (1992) Rapid desensitization of muscarinic $\mathrm{m}_{3}$ receptor-stimulated polyphosphoinositide responses. Mol. Pharmacol. 42, 1042-1048.

Tobin A. B., Keys B., and Nahorski S. R. (1993) Phosphorylation of a phosphoinositidase $\mathrm{C}$-linked muscarinic receptor by a novel kinase distinct from $\beta$-adrenergic receptor kinase. FEBS Lett. 335, 353-357.

Tobin A. B., Keys B., and Nahorski S. R. (1996) Identification of a novel receptor kinase that phosphorylates a phospholipase $\mathrm{C}$ linked muscarinic receptor. J. Biol. Chem. 271, 3907-3916.

Yokota Y., Sasai Y., Tanaka K., Fujiwara T., Tsuchida K., Shigemoto R., Kakizuka A., Ohkubo H., and Nakanishi S. (1989) Molecular characterization of a functional cDNA for rat substance P receptor. J. Biol. Chem. 264, 17649-17652.

Yokota Y., Akazawa C., Ohkubo H., and Nakanishi S. (1992) Delineation of structural domains involved in the subtype specificity of tachykinin receptors through chimeric formation of substance P/substance, $\mathrm{K}$ receptors. EMBO J. 11, 3585-3591.

Yu S. S., Lefkowitz R. J., and Hausdorff W. P. (1993) $\beta$-Adrenergic receptor sequestration: a potential mechanism of receptor resensitization. J. Biol. Chem. 268, 337-341. 